\title{
Pertanggungjawaban Pemerintah terhadap petugas PPS dan KPPS sebagai korban penyelengaraan pemilihan umum
}

\author{
Faisal Adhyaksa
}

Faisal Adhyaksa; Magister Ilmu Hukum Universitas Airlangga; Kampus B Unair, Jl. Dharmawangsa Dalam Selatan; Surabaya; 60286; Jawa Timur; Indonesia

\section{ARTICLEINFO}

\section{Article history:}

Received 2020-01-18

Received in revised form

2020-02-01

Accepted 2019-04-01

\section{Kata kunci:}

Pertanggungjawaban; Pemerintah;

Petugas PPS; Petugas KPPS;

Pemilihan Umum.

\section{Keywords:}

Responsibility; Government; PPS officer; KPPS Officer; General election.

DOI: https://doi.org/10.26905/ idjch.v11i1.3530.

\section{How to cite item:}

Adhyaksa, F. (2020). Pertanggungjawaban Pemerintah terhadap petugas PPS dan KPPS sebagai korban penyelengaraan pemilihan umum. Jurnal Cakrawala Hukum, 11(1), 21-30. doi:10.26905/ idjch.v11i1.3530.

Corresponding Author:

* Faisal Adhyaksa.

E-mail address: faisaladhyaksa@gmail.com

\section{Abstrak}

Pemilihan umum serentak Negara Indonesia merupakan agenda demokrasi terbesar di dunia. Pada tahun 2019 prosesi ini diwarnai oleh banyak problematika pelaksanaan. Problem tersebut mengakibatkan beberapa korban baik korban kekerasan bahkan meninggal dunia. Negara melalui lembaga Komisi Pemilihan Umum setidaknya ikut andil dalam bertanggungjawab atas peristiwa ini. Penelitian ini menggunakan metode yuridis normatif dengan seluruh aspek pertanggungjawaban hukum baik dari ranah hukum pidana, perdata, administrasi, bahkan dari pertanggungjawaban politik. Beberapa aspek hukum tersebut yang tidak dapat untuk dituntut adalah aspek pidana dan politik, namun di sisi lainnya dapat dituntut dalam hal keperdataan dan administratif sebagai akibat sifat juristic person dari negara. Pertanggungjawaban dari ranah keperdataan merupakan bentuk dari pertanggungjawaban mutlak. Pada ranah hukum administrasi negara hilangnya penegakan atas AAUPB menjadi perhatian serius dalam manajemen publik yang semakin condong ke arah gaya privat. Perlu adanya monitoring yang ketat terhadap pelaksanaan pemilu di Indonesia dikarenakan kekuatan politik yang begitu besar yang justu mengancam pada penegakan hukum.

\section{Abstract}

The general election of the Indonesian State are the largest democratic progress in the world. At years 2019, process of election was incident by implementation problems. The problem resulted in several victims of violence and even died. The National Election Commission, will at least take part in being responsible for this incident. This research used normative juridical methods. This method using fundamental normative and theories analyse. Aspects of legal liability are from criminal law, civil law, administration, and even from political liability. Some aspects of the law that cannot be prosecuted are criminal and political aspects, but on the other side they can be prosecuted in terms of civil and administrative consequences as a result of the juristic person of the state. Accountability from the realm of civilization is a form of absolute accountability. In the realm of state administration law the loss of enforcement of AAUPB is a serious concern in public management which is increasingly leaning towards the private style. There is a need for monitoring of the implementation of elections in Indonesia because of the enormous political power which only threatens law enforcement. 


\section{Jurnal Cakrawala Hukum, Volume 11 No. 1 Juni 2020 \\ ISSN PRINT 2356-4962 ISSN ONLINE 2598-6538}

\section{Latar Belakang}

Negara Indonesia merupakan salah satu negara demokrasi yang terbesar di dunia. Pada tahun 2019 dilaksanakan pesta demokrasi terbesar yang pernah ada sepanjang sejarah Indonesia. Hal ini disebabkan dalam satu momen terjadi pemilihan serentak baik dari kekuasaan eksekutif Presiden dan wakil presiden serta dari kekuasaan legislatif. Pesta demokrasi terbesar di Indonesia telah memasuki masa final dengan ditetapkannya pemenang pada tanggal 22 Mei 2019. Namun yang perlu diperhatikan di sini adalah telah banyak terjadi momen-momen yang telah menciderai agenda demokrasi ini.

Berdasarkan data statistik, terdapat korban meninggal akibat penyelenggaraan pemilu terbesar ini dengan jumlah 326 orang yang tersebar di beberapa wilayah di Indonesia (jawapos, 27 April 2019). Faktor-faktor yang di rinci dalam kasus tersebut adalah karena kelelahan, sakit, Kecelakaan, Penganiayaan dan bahkan sampai bunuh diri. Hal ini mencakup segala pekerja mulai dari Pegawai KPU maupun Bawaslu dan terutama yang luput dari perlindungan adalah PPS dan KPPS.

Momen politik merupakan momen yang sangat sensitif terutama di negara Indonesia yang memiliki budaya heterogen. Suasana politik di negara Indonesia sangat marak dengan dinamika. Demokrasi mulai berkembang cepat sejak era reformasi. Namun perkembangan demokrasi di Indonesia masih mencapai tahap yang belum dewasa. Hal ini diwarnai dengan banyaknya metode-metode politik praktis demi kepentingan kelompok atau golongan. Suasana ini diperparah dengan lunturnya kepercayaan masyarakat yang belum pulih atas militer yang pernah memimpin pada orde baru. Berbagai macam cara dilakukan pemerintah demi mengembalikan kepercayaan rakyat terutama pada TNI/POLRI. Di sisi lain kepercayaan masyarakat mulai pulih pada sektor pelayanan publik yang sudah mengalami per- baikan di beberapa daerah dengan menerapkan good governance.

Jika dilakukan studi perbandingan pada negara dengan sistem demokrasi yang sama besarnya, kebanyakan sudah menggunakan elektronik voting (e-voting). E-voting digunakan untuk menghindari kesalahan perhitungan dan meningkatkan validitas data yang diolah. Era informasi dan teknologi menuntut penggunaan sistem terintegrasi yang cepat di sistem pemerintahan. Era e-government memang telah masuk ke Indonesia namun penerapan belum menyeluruh. Validitas hanya sampai pada pemutakhiran data kependudukan sebagai sarana pemilih tetap, tetapi belum masuk ke dalam proses penghitungan. Hal inilah yang menjadikan peluang pihak-pihak tertentu memberikan susana kurang kondusif pada proses demokrasi. Celah ini yang kemudian menjadikan korban-korban proses demokrasi berjatuhan.

Pemerintah baik pihak eksekutif dan legislatif belum menerapkan perlindungan secara menyeluruh bagi aparat yang berada di lembaga pemilihan umum. Sekalipun dalam UndangUndang Pemilihan Umum telah mengatur beberapa hal termasuk kewenangan dari aparat yang ada di lembaga pemilihan umum, tetapi tidak mengatur tentang resiko akibat pekerjaan tersebut. Penelitian ini yang perlu dianalisis adalah pertanggungjawaban dari KPU sebagai lembaga pemerintah atas peristiwa yang diakibatkan pada tugas yang diberikan kepada masyarakat.

\section{Metode}

Jenis penelitian yang digunakan dalam meneliti permasalahan ini ialah penelitian hukum normatif. Metode yang digunakan dalam penelitian ini adalah yuridis-normatif. Metode ini menggunakan pendekatan perundang-undangan dan pendekatan filosofis (Mahmud, 2005). Pendekatan perundang-undangan menjadi fokus sekaligus tema sentral dalam suatu penelitian. Pendekatan perbandingan dilakukan dengan mengadakan 
studi perbandingan hukum dengan hukum negara lain atau hukum dari suatu waktu tertentu dengan hukum dari waktu yang lain. Bahan hukum yang dipergunakan oleh peneliti dalam melakukan penelitian ini baik bahan hukum primer, bahan hukum sekunder dan bahan hukum tersier.

\section{Pembahasan}

\subsection{Kedudukan pemerintah}

Pemilu serentak di Indonesia pada tahun 2019 bisa terbilang pertama kalinya dengan istilah pemilu lima kotak. Hal ini tidak terlepas dari sebuah putusan Mahkamah Konstitusi yang mendukung adanya agenda pemilu seperti ini berdasarkan Putusan No. 14/PUU-XI/2013 yang diajukan oleh Effendi Gazali dkk. Alasan efektif dan efisien mungkin sudah tidak sebanding dengan resiko yang dihadapi para petugas pelaksana. Hal kontradiksi dalam putusan tersebut adalah belum jelasnya pemilu serentak antara pusat daerah. Banyak hasil evaluasi dan kritik bahwa pemilu pusat dan daerah memang sudah sewajarnya tidak dijadikan dalam satu agenda pemilihan umum.

Teori Hans Kelsen tentang tanggung jawab hukum menyatakan bahwa seseorang bertanggung jawab secara hukum atas suatu perbuatan tertentu dan/atau bahwa dia memikul tanggung jawab hukum. Pengertian subyek berarti bahwa dia bertanggung jawab atas suatu sanksi dalam hal perbuatan yang bertentangan. Ada pandangan dari penganut aliran hukum era klasik atau tradisional. Pertanggungjawaban ini dibagi menjadi dua macam, yaitu pertanggungjawaban berdasarkan kesalahan dan pertanggungjawaban mutlak.

Eratnya pertanggungjawaban di sini adalah karena adanya pertemuan antara dua atau subyek hukum yang masing-masing subyek ini memiliki hak dan kewajibannya masing-masing. Bertemunya masing-masing hak dan kewajiban ini dapat diakibatkan karena adanya perikatan atau pelanggaran dimana salah satu subyek hukum melanggar hak subyek hukum lainnya, dan oleh karena itu pelanggar memiliki kewajiban untuk menyelesaikannya (bertanggungjawab).

Subyek hukum yang pertama adalah dari pihak pemerintah dalam hal ini lembaga-lembaga Pemilihan Umum, subyek hukum selanjutnya adalah petugas PPS dan KPPS. Perikatan antar kedua subyek ini adalah saat proses perekrutan petugas. Perekrutan pada proses ini adalah pengikatan antar subyek hukum dengan memberikan masing-masing hak dan kewajiban. Studi kasus yang terjadi adalah banyaknya tekanan-tekanan yang diberikan kepada petugas PPS dan KPPS. Tekanan ini bukan hanya berasal dari pemerintah sebagai subyek hukum yang pertama tetapi adanya tekanan dan ancaman dari luar. Sejatinya minimal ada pelindungan yang diberikan dari lembaga pemerintah untuk melindungi. Perlindungan biasanya terjadi pada saat proses, tetapi pasca proses juga tetap membutuhkan adanya perlindungan.

Subyek hukum di sini yang perlu diperhatikan adalah kemampuan untuk bertanggungjawab. Pada konsep ilmu hukum, subyek hukum diartikan sebagai sesuatu yang dapat mengemban hak dan kewajiban. Subyek hukum tidak hanya mencakup orang (persoon), namun juga badan hukum. Badan hukum dalam ilmu hukum empiris sering kali diterjemahkan sebagai korporasi ataupun badan usaha, namun cakupannya lebih luas dari pandangan tersebut. Jika ditinjau dari ranah hukum perdata, pandangan organ pemerintah termasuk ke dalam subyek hukum disebabkan karena adanya kepemilikan harta dan aset atas lembaga tersebut (Ridwan, 2013).

Pandangan lain organ pemerintah sebagai subyek hukum yaitu karena adanya sifat juristic person. Kedudukan pemerintah dalam hal ini menjadikan lembaga pemerintah termasuk di dalamnya pejabat pengambil keputusan menjadikan subyek hukum Pejabat pembuat keputusan mendapat pembebanan tanggung jawab atas keputusan yang dibuat. Penetapan dan keputusan pengangkatan 
petugas pemilu baik itu PPS maupun KPPS merupakan keputusan pejabat negara. Oleh karena itu segala akibat dari keputusan tersebut juga dapat dipertanggungjawabkan.

Sikap pemerintah sebagai negara hukum dengan negara kesejahteraan menjadi tolak ukur posisi negara Indonesia saat ini. Negara hukum sudah mengalami kritik yang tidak sedikit karena sifat pasifnya pemerintah sebagai penjaga malam. Sikap pemerintah dalam hal ini masih menjadi transisi ke dalam negara kesejahteraan. Pada konsep negara kesejahteraan pemerintah di tuntut untuk dapat aktif sebelum ada peristiwa terjadi. Kasus petugas PPS dan KPPS menjadi salah satu sikap pemerintah yang kurang holistik dalam melindungi proses pemiihan umum serentak. Pada satu sisi sebenarnya pemerintah sudah melaksanakan perlindungan terhadap pelaksanaan pemilu bahkan sampai pada hari pencoblosan. Pada sisi lainnya pemerintah masih kurang memperhatikan aspek keselamatan dari pelaksana lapangan petugas PPS dan KPPS pasca pelaskanaan. Proses perhitungan suara bahkan pengawalan sampai penetapan pemenang membutuhkan pengawalan tanpa melihat status pelaksana dari petugas pemilu.

Kondisi demokrasi di Indonesia memiliki warna tersendiri. Hal ini dapat terlihat dari proses demokrasi yang dinamis. Perlu adanya pengamanan tersendiri di negara Indonesia dengan tidak melibatkan proses otoritarian. Hal ini disebabkan.

\subsection{Pertanggungjawaban pidana}

Jika ditinjau dari falsafah hukum, badan hukum baik dalam bentuk privat atau negara dapat dikategorikan ke dalam bentuk juristic person. Bentuk ini sebagai lawan dari natural person. Pengertian ini mengacu kepada pertanggungjawaban secara kolektif individu di dalam badan hukum. Yuristic person terdiri dari beberapa individu yang menggerakkan badan hukum. Aktifitas menggerakkan ini jika terdapat unsur pidana maka, seke- lompok individu itulah yang dapat dikenakan sanksi pidana. Pertanggungjawaban pidana dititikberatkan pada pengambil keputusan dari perbuatan yang terdapat unsur pidana, beserta unsur penyertaan dalam pasal 56 KUHP. Perbuatan pidana di sini bukan hanya dilakukan secara sengaja (dolus) tetapi juga dilakukan secara culpa (kealpaan).

Unsur pidana dalam peristiwa pemilu 2019 pada dasarnya tidak dapat dilakukam penuntutan bahkan jika ditinjau dari sudut pandang kealpaan. Hal ini disebabkan karena adanya alasan pembenar sebagamana pasal 50 KUHP. Pejabat ataupun aparat atas dasar jabatan yang menjalankan UndangUndang tidak dapat dipidana. Pasal tersebut menghapuskan unsur subyektif, yaitu kesalahan. Unsur pembenar dalam pasal tersebut sejatinya disebabkan karena adanya perbenturan kewajiban hukum. Pada satu sisi KPU menjalankan kewenangannya berdasarkan konstitusi dan undangundang pemilu, di satu sisi lainnya menimbulkan korban jiwa. Hal ini dapat juga dilihat dalam peristiwa eksekutor pidana yang juga melakukan tugasnya. Pada peristiwa ini mengakibatkan hapusnya penuntutan pada sifat pidana.

Penekanan unsur pidana justru lebih mengarah kepada petugas KPPS sebagaimana diatur ke dalam pasal 489, 499, 503, dan 537 Undang-Undang Pemilu jika terdapat kelalaian dalam proses pemungutan suara. Melihat keadaan di lapangan dan ketatnya peraturan, maka resiko terhadap keselamatan petugas perlu di pertimbangkan kembali.

\subsection{Pertanggungjawaban perdata}

Berdasarkan perjanjian kerja pasal 52 Undang-Undang Ketenagakerjaan, maka berlaku asas keperdataan yaitu antara pemberi kerja dan penerima kerja. Asas pacta sun servanda berlaku dalam pelaksanaan perjanjian kerja ini. Artinya, dengan sahnya syarat perjanjian tersebut maka berlaku pula hak dan kewajiban kedua belah pihak. 
Permasalahan yang terjadi sampai saat ini adalah belum di atur secara rinci tentang manajemen resiko perjanjian kerja.

Perjanjian kerja dengan resiko selama ini hanya mengarah kepada petugas ataupun pekerja yang bekerja di bidang proyek dengan resiko kecelakaan atau bahkan kematian yang lebih besar dari pekerjaan manapun. Padahal, semua pekerjaan terdapat resiko kecelakaan kerja, sakit, atau bahkan kematian.

Permasalahan yuridis lebih lanjut adalah status KPU yang dalam hal ini bukan sebagai perusahaan atau badan hukum perdata dan status petugas PPS dan KPPS yang bukan sebagai apratur sipil dengan perjanjian kerja. Namun tetap pada hakikatnya secara perjanjian perdata dan asas perjanjian sebagai undang-undang, KPU dapat digugat tentang ganti rugi dari segala resiko yang terjadi di lapangan. Melihat celah ini, KPU sebagai pemerintah mulai memberikan tanggung jawab dengan memberikan santutan serentak pada 3 Mei 2019. Besaran santunan yang sampai meninggal dunia mencapai 36 juta per orang. Berdasarkan tindakan pemerintah tersebut, maka kebijakan pemerintah dalam memberikan santunan kepada korban KPPS merupakan hubungan keperdataan, bukan hubungan hukum publik sebagaimana PPPK dalam Undang-Undang ASN.

Perbuatan melawan hukum (Moegni, 1982) perbuatan melawan hukum terdapat dua kategori, yaitu perbuatan yang ditujukan pada diri sendiri dan perbuatan yang ditujukan pada badan hukum. Berdasarkan dari analisa tersebut dalam peristiwa ini termasuk dalam ketagori yang kedua. Badan hukum publik melibatkan adanya kesalahan dalam organ tersebut. Kelalaian akan pengawasan dan pengamanan petugas menjadi hubungan sebabakibat dalam peristiwa ini.

Pasal 166 Undang-Undang Ketenagakerjaan, dalam hal hubungan kerja berakhir karena pekerja/ buruh meninggal dunia, kepada ahli warisnya. Santunan diberikan kepada ahli waris petugas PPS dan
KPPS yang meninggal dunia, temasuk juga santunan kepada petugas yang mengalami kecelakaan. Peraturan mengenai santunan ini diatur ke dalam Peraturan Pemerintah Nomor 44 tahun 2015. Pada aturan tersebut memuat beberapa hal antara lain JKK (Jaminan Kecelakaan Kerja) yang dalam hal ini diberikan kepada petugas yang masih hidup yang mengalami kecelakaan kerja dalam proses pemilu 2019. Sedangkan pada yang meninggal di berikan JKM (Jaminan Kematian).

Sifat abscurd terdapat dalam rumusan pasal 4 Peraturan Pemerintah ini. Pertama jika ditinjau dari peraturan pemerintah, yaitu rumusan pasal tersebut petugas pemilu dianggap sebagai ASN sebagaimana rumusan pasal tersebut bahwa pemberi kerja berasal dari penyelenggara negara. Kedua, jika ditinjau dari UU ASN, petugas PPS dan KPPS hubungan hukumnya hanya bersifat keperdataan yang disetarakan dengan ketenagakerjaan (industrial). Pandangan yang kedua ini lebih tepat jika disinkronkan dengan syarat-syarat ASN yang tidak terpenuhi dalam perekrutan petugas PPS dan KPPS.

Jika menelaah secara historis dan juga status petugas, maka kewajiban pemerintah minimal memberikan perlindungan secara Undang-Undang Nomor 13 tahun 1992. Pertama, bidang pengarahan yang pada bidang ini pemerintah sudah memberikan perlindungan Kedua, bidang hubungan kerja termasuk ke dalamnya sejak petugas direkrut pemerintah juga sudah memberikan perlindungan. Ketiga, jaminan kesehatan dan keselamatan kerja.

Ranah ketiga ini yang terdapat kelalaian dalam melindungi. Sebenarnya jika di analisis dari resiko pekerjaan petugas ini resiko dianggap tinggi terutama berhadapan oleh tim sukses partai politik dan adanya oknum-oknum tertentu. Kelalaian di sini karena salah membuat prioritas kesehatan dan keselamatan kerja petugas, yang dalam hal ini hanya dianggap beresiko rendah. Anggapan resiko rendah dalam peristiwa ini disebabkan paradigma bahwa hanya pekerja pabrik saja yang menadapat- 


\section{Jurnal Cakrawala Hukum, Volume 11 No. 1 Juni 2020}

ISSN PRINT 2356-4962 ISSN ONLINE 2598-6538

kan kategori resiko tinggi terutama yang berhubungan dengan barang-barang berbahaya. Keempat, jaminan sosial yang diberikan juga termasuk kategori lalai yang mana dari awal tidak terdapatnya jamninan sosial meskipun dalam pekerjaan dibatasi dengan waktu tertentu. Oleh karena itu dalam peristiwa ini pemerintah benarbenar bertanggungjawab penuh dengan memberikan pesangon kepada korban bukan dengan JKM.

\subsection{Pertanggungjawaban administratif}

Tanggungjawab pemerintah dalam peristiwa ini merupakan bentuk implementasi dari good governance. Prinsip maupun asas dalam good governance tertuang ke dalam Undang-Undang Nomor 28 tahun 1999 dan Undang-Undang Nomor 30 tahun 2014. Asas ini sering dikenal di pemerintah Indonesia sebagai Asas-Asas Umum Pemerintahan yang Baik (AAUPB).

Dasarnya penerapan good governance bertujuan penekanan aspek swasta dan penekanan pada tanggungjawab pemerintah (Keban, 2004). Asasasas dalam good governance menjiwai setiap tindakan pemerintah agar tidak terjadi penyalahgunaan wewenang dan penyetaraan keadilan di mata hukum. Makna kebijakan adalah kebijakan publik adalah apapun pilihan maupun sikap pemerintah untuk melakukan sesuatu atau justru tidak melakukan. Pada sisi kebijakan, sikap pemerintah untuk memberikan santunan merupakan suatu kebijakan. Pemberian santuntan dipilih sebagai perbuatan, sebab diamnya pemerintah juga dapat diartikan suatu kebijakan. Kebijakan yang justru mendiamkan masalah publik akan berdampak pada organ pemerintah itu sendiri termasuk pejabat pembuat keputusan.

Sifat dari kebijakan pemerintah untuk memberikan santunan ini termasuk penerapan akan asas akuntabilitas. Asas akuntabilitas dalam UndangUndang Nomor 28 tahun 1999 merupakan asas pertanggungjawaban organ pemerintah. Pertanggung- jawaban dalam sudut pandang hukum administrasi negara ini merupakan pertanggungjawaban kepada atasan dan juga kepada masyarakat. KPU tidak memiliki pertangggungjawaban kepada atasan karena merupakan lembaga tinggi negara. Namun, KPU memiliki pertanggungjawaban kepada masyarakat.

Penerapan asas pemerintahan yang baik sejatinya diperlukan dalam penyelenggaraan negara yang profesional dan memberantas KKN. Suatu bentuk tanggungjawab secara ranah administratif merupakan pergerakan otoritas KPU untuk menggunakan kewenanganya dalam melaksanakan pemilu 2019 termasuk manajemen resiko yang ada di dalamnya. Manajemen resiko pada pemilu tahun ini perlu dijadikan bahan evaluasi agar tidak terjadi hal yang sama di pemilu berikutnya.

Asas profesionalisme yang menjadi salah satu elemen pemerintahan yang baik juga perlu di terapkan pada proses pemilihan umum berikutnya. Profesionalisme ini adalah untuk menghindari adanya pekerjaan campur-campur dari para petugas lapang dalam pelaksanaan pemilu. Masalah pemilu demokratis merupakan masalah yang strategis yang perlu perhatian serius bagi pemerintahan di Indonesia. Segala jenis pekerjaan sudah saatnya diserahkan pada orang-orang yang benar-benar sudah profesi, dilatih dengan serius dan mau berkomitmen.

Banyak dari petugas lapang pemilu berasal dari masyarakat yang pada dasarnya memiliki pekerjaan atau kesibukan sebelumnya. Pemberian pekerjaan penuh waktu dan/atau paruh waktu dengan membebankan kepada orang-orang yang bukan semestinya merupakan penyimpangan dari asas ini. Sekalipun hanya mengejar dari efektifitas maupun efisiensi suatu sumberdaya, bukan berarti mengorbankan essensi profesionalisme itu sendiri. Makna professional, berasal dari asal kata profesi, yang berarti orang yang membidangi suatu bidang pekerjaan. Seseorang dianggapp professional jika benar-benar memiliki satu pekerjaan tersebut, 


\section{Pertanggungjawaban Pemerintah terhadap petugas PPS dan KPPS sebagai korban penyelengaraan pemilihan umum}

Faisal Adhyaksa

berkomitmen dan berkompeten. Asas profesionalisme menjadi suatu asas wajib yang harus dimiliki organ publik.

Perbedaan mendasar antara organ publik dan organ privat tentang gaya pengelolaan sebaiknya memang tidak dapat dicampuradukkan. Otoritas negara tentang yurisdiksi dan regulasi menjadi perbedaan mendasar antara kedua organ tersebut, terutama yang menyangkut hajat hidup orang banyak. Pengarahan pada gaya sektor swasta pada pemerintahan di era sekarang sudah mencapai batasnya. Pemerintah sebagai organ publik sudah mulai memikirkan untuk tidak mengabaikan hal ini setelah peristiwa pemilu 2019.

Perekrutan petugas PPS dan KPPS lebih baik menggunakan pihak ketiga yang berstatus lembaga swasta sebagai sarana perekrutan dalam pemilihan berikutnya. Hal ini untuk menjawab status pekerjaan, hak, dan kewajiban atas petugas dan KPPS. Jika berstatus menggunakan pihak ketiga maka sudah jelas penyelenggara bukan negara, dan terpisah dari status ASN. Hak dan kewajiban murni diberikan dari sektor ketenagakerjaan seperti BPJS atas perlindungan dari petugas, dan jika terjadi sengketa juga terdapat mekanisme yang jelas.

Alternatif ini juga menjawab asas efektifitas dan efisiensi dari perekrutan petugas dengan masa kerja kurang dari satu tahun. Jika distatuskan sebagai ASN seperti PPPK maka akan timbul permasalahan dari efektifitas dan efisiensi terutama dari segi anggaran. Jika terdapat sengketa kerja dengan hal seperti ini akan terjadi suatu kebingungan apakah akan diselesaikan oleh Pengadilan Tata Usaha Negara atau justru Pengadilan Perindustrian. Di satu sisi tuntuan pejabat publik KPU sebagai pemberi kerja sangat tinggi mengakibatkan beberapa petugas justru bunuh diri. Kompetensi peradilan menjadi sulit menjangkau masalah seperti ini mengingat pada posisi kasus ini kedudukan negara menjadi sangat superior.

Berdasarkan status petugas PPS dan KPPS yang tidak ada larangan secara tegas dari kom- ponen ASN dalam hal ini banyak merugikan dari komponen masyarakat yang justru bukan berasal dari golongan ASN. Masalah terjadi ketika terdapat resiko kecelakaan kerja atau bahkan kematian. Sedang dari golongan ASN mereka mendapat hak dan perlindungan yang sangat jelas jika terjadi sesuatu dalam menjalankan tugas. Negara-negara maju di dunia sudah mulai mengurangi penggunaan Sumber Daya Manusia dengan mengalihkan pekerjaan tersebut kepada teknologi. Teknologi di era industri 4.0 bahkan sudah merambah ke semua sektor, termasuk sektor pemerintahan misalnya dengan adanya e-governtment.

Era e-governtment sudah hampir merambah ke semua sektor pemerintahan. Beberapa yang belum digunakan secara penuh adalah penerapan dalam sistem demokrasi. Penggunaan e-governtmen dan sistem informasi manajemen hanya berhenti pada data kependudukan sebagai DPT, selebihnya perhitungan masih dilakukan manual. Proses perhitungan maual inilah yang menjadi celah pemilu tahun 2019. Banyak oknum yang berusaha membuat kericuhan denga melalui cara-cara melawan hukum, mulai dari penekanan, pengancaman yang berujung pada kesalamatan petugas bahkan psikis yang menyebabkan kematian. Penggunaan $e$-voting dapat meminimalisir terjadinya korbankorban pemilu. Diperlukan pengawasan yang sangat ketat apabila akan diaplikasikan sistem evoting tersebut di kemudian hari. Di samping adanya rawan manipulasi dari sistem itu sendiri, juga ada serangan berupa cyber juga menjadi perhatian khusus dalam penerapan e-voting.

Jalur pemilihan dengan melalui sistem tersebut menjadi cukup efektif jika dapat dilakukan dengan monitoring dari masyarakat yang ketat dan transparan. Sistem secara daring dikenal dengan kekakuannya sehingga mampu meminmalisir adanya kesalahan perhitungan dan sabotase yang dilakukan oleh beberapa pihak tertentu. Permasalahan yang sampai saat ini adalah tentang pertanggungjawaban administratif pejabat KPU pada 
peristiwa ini belum ditunaikan. Berdasarkan analisa peristiwa tersebut sebenarnya terjadi pelanggaran ringan secara administratif.

Sebagaimana pasal 8 Undang-Undang Nomor 30 tahun 2014 menyatakan bahwa pejabat atau organ pemerintahan dalam menjalankan kewenangan harus sesuai dengan peraturan perundang-undangan dan AAPUB. Kedua unsur ini mempunyai sifat kumulatif, yang artinya menjadi satu kesatuan. Unsur pertama dari lembaga KPU sudah memenuhi karena menjalankan amanat dari

Undang-Undang Pemilu. Unsur kedua, yaitu sesuai AAUPB. Asas profesionalisme sebenarnya

bukan menjadi bagian dari Undang-Undang Administrasi Pemerintahan namun keberlakuannya terdapat di dalam Undang-Undang Nomor 28 Tahun 1999. Keberlakuan AAUPB yang tersebar di luar Undang-Undang Administrasi Pemerintahan diakui ke dalam pasal 10 ayat 2 yang berbunyi:

"Asas-asas umum lainnya di luar AUPB sebagaimana dimaksud pada ayat (1) dapat diterapkan sepanjang dijadikan dasar penilaian hakim yang tertuang dalam putusan Pengadilan yang berkekuatan hukum tetap."

Pelanggaran dari asas ini sebenarnya bisa dilakukan penegakan. Pasal 80 Undang-Undang Administrasi Pemerintahan telah membetikan ketentuan sebagai pelanggaran ringan jika melanggar AAUPB. Sanksi dari pelanggaran ringan dapat berupa teguran lisan, teguran tertulis, atau penundaan kenaikan pangkat jabatan. Permasalahan yang terjadi adalah sampai saat ini sanksi dari administratif sebagai bentuk pertanggungjawaban belum juga dilaksanakan. Hal ini menjadi salah satu inventaris masalah dalam keberlakuan hukum administrasi negara di Indonesia.

\subsection{Pertanggungjawaban Politik}

Pelaksanaan pemilihan umum di Indonesia sangat kental dengan aura politik praktis. Hukum seolah-olah menjadi tidak memiliki kekuatan menyelesaikan masalah-masalah pemilihan umum. Dominansi politik golongan terutama menjadi salah satu isu penyebab masalah-masalah pemilihan umum di Indonesia. Dominansi politik golongan ini disebabkan adanya kesepakatan di ranah elit politik untuk tidak membuka lebar-lebar jalur independen atau jalur non partai politik. Masingmasing partai politik justru membawa dogma, ideologi, bahkan politik praktis melalui kaderisasi di masyarakat bahkan di usia yang sangat muda.

Pemuda-pemuda yang sudah membawa dogma dan bekal ini kemudian menjadi senjata yang efektif dalam menunjang cita atau tujuan suatu golongan. Korban-korban yang berjatuhan ada kemungkinan hanya dianggap menjadi keniscayaan dalam perang politik ini sehingga tidak mungkin dapat dihindari. Pada sisi pertanggungjawaban tetap kepada pemerintah yang sedang berjalan, bukan pada faktor penyebab. Hal ini juga yang menyebabkan rasa persatuan menjadi berkurang.

Teori hukum post modern pernah diungkap (Sugiharto, 1996). Sebagai konsekuensi pernah berlakunya kekuasaan secara koersif, maka muncul kembali adanya tribalisme, yaitu suatu perbuatan yang mementingkan suku, kelompok dan golongannya sendiri. Pementingan suku seperti kedaerahan sudah mulai terasa dengan dominansi kelompok kedaerahan di aksi-aksi tertentu. Pementingan parpol juga demikian pada plotting pemilihan umum bahkan sampai pemilihan di pemerintahan.

Aliran critical legal studies beberapa waktu terakhir bereaksi keras dalam mengkritik tentang tumpulnya hukum di era post-modern. Salah satu yang dikritik dari peristiwa politik adalah bahwa hukum hanya berperan dalam formalisme saja. Pemikiran formalisme hukum, hukum memiliki sifat imperatif. Hal ini disebabkan bahwa hukum dibuat oleh negara. Negara memiliki alat-alat pelengkapan negara seperti DPR dan pemerntah eksekutif untuk membuat hukum. Hal inilah yang menyebabkan hukum justru hanya menjadi alat atau produk politik. 
Alat kelengkapan negara yang bertugas membuat hukum tadi berasal dari golongan partai politik. Negara Indonesia disamping memiliki DPR dan presiden, juga memiliki lembaga yang bertugas untuk menjalankan hukum, yaitu yudikatif. Pemerintah dengan DPR memiliki otoritas untuk membuat undang-undang, yang akan diterapkan oleh hakim di pengadilan. Hal inilah yang mengakibatkan bahwa hukum tidak dapat lagi dilihat dalam aspek substantifnya, namun hanya pada aspek legal formalnya. Hukum hanya bertindak sebagai alat pengesahan dan penegakan dari produk politik.

Unsur penyebab pada sudut pandang ini dapat ditinjau berdasarkan teori Conditio Sine Qua Non dari Von Buri (Sofyan, 2016). Teori ini menarik pertanggungjawaban sampai kepada sebab dan syarat dengan nilai yang sama. Artinya pihak-pihak terkait memiliki nilai yang sama dalam menyebabkan terjadinya persitiwa atau korban. Jika ditarik dari awal pelaksanaan maka teori ini dapat menjelaskan sebuah kausa yang berasal dari lembaga politik itu sendiri. Tuntutan atas lembaga politik yang memaksa lembaga pemerintah KPU menyebabkan korban berjatuhan. Lembaga politik seperti partai politik mengakibatkan panasnya suasana politik di Indonesia. Hal ini disebabka ikut andilnya ke dalam sistem penyelenggaraan.

Hans Kelsen dalam pendapatnya terhadap pertarungan politik dan juga hukum mengatakan bahwa peranan negara sebagai pembentuk hukum, politik hanya mempelajari pertrungan tenagatenaga sosial yang dalam hal ini dianggap sebagai akibat pada faktor-faktor kekuasaan yang nyata. Politik tidak menitikberatkan sifat teknis pada hukum (Isjwara, 1999).

Memperkuat pendapat dari hans kelsen, Sherwood menyatakan bahwa politik seharusnya mengetahui faktor extra-legal, yaitu faktor kekuasaan yang turut mempengaruhi pembentukan hukum. Pada kritik ini para aktor politik sendiri lupa bahwa ternyata essensi keberadaan hukum itu sendiri justru menyelenggarakan tujuannya. Berangkat dari pendapat tersebut paradigma aktor politik sekarang lebih banyak kepada paradigma untuk melancarkan tujuannya tanpa melihat adanya kausa formal yang ada di negara.

Analisa politik dapat dipetakan bahwa ada dua pendekatan sudut pandang. Pertama, politik sebagai etik yaitu memilih dan menentukan tujuan kehidupan bermasyarakat yang pada seharusnya diperjuangkan. Kedua, politik sebagai teknik yaitu tentang menentukan cara untuk mencapai tujuan kehidupan bermasyarakat yang telah dipilih dan ditentukan oleh politik sebagai etik. Jika kedua hal ini benar-benar dilakukan maka tata kehidupan bermasyarakat akan stabil dan aman. Permasalahan dalam kasus ini adalah melencengnya antara etik dan praktik. Pada kenyataannya politik sebagai teknik justru tidak berlandaskan kepada etik. Pengembalian jalur kepada etik dapat dijadikan sebagai salah satu alternatif dalam setiap agenda politik di Indonesia sehingga tidak timbul politikpolitik yang justru tidak sejalan dengan tujuan negara. Timbulnya politik golongan yang mengarah kepada oligarki semu, ataupun politik pribadi-turunan merupakan pelaksanaan politik praktik yang dilakukan tanpa etik.

Kritik terhadap putusan MK . 14/PUU-XI/ 2013 yang diajukan oleh pakar komunikasi politik selajutnya dapat di evaluasi sebelum terjadinya pemilihan serentak selanjutnya. Tujuan melaksanakan pemilihan umum serentak akan sangat mungkin di muati oleh kepentingan-kepentingan yang ingin mengambil andil dalam keruhnya masalah dinamika demokrasi Indonesia. Constitusional question memang membatasi kewenangan dari mahkamah konstitusi sehingga memberikan pelaksanaan teknis kepada KPU dalam pelaksanaan pemilu 2019. Evaluasi dari putusan ini harus sejalan dengan evaluasi holistik pola manajerial KPU untuk pemilu beikutnya.

Agenda politik demokrasi di negara-negara maju sudah menggunakan sistem politik dengan 


\section{Jurnal Cakrawala Hukum, Volume 11 No. 1 Juni 2020 \\ ISSN PRINT 2356-4962 ISSN ONLINE 2598-6538}

tingkat pengawasan sampai titik individu di masyarakat. Salah satu negara seperti Amerika Serikat bahkan menggunakan sistem terintegrasi, bukan hanya pada e-voting namun surat pencoblosan juga di simpan ke dalam mesin, bisa langsung digunakan dalam pengawasan.

\section{Simpulan}

Kedudukan pemerintah dalam hal ini sebagai juristic person mengakibatkan adanya tanggungjawab mutlak. Tanggung jawab tersebut merupakan tanggung jawab keperdataan yang diakibatkan adanya hubungan kerja secara privat. Sudut pandang kausalistik salah satunya justru berasal dari sistem politik yang berlaku di negara Indonesia. Penekanan-penekanan yang berasal dari sistem tersebut mengakibatkan adanya perilaku kekerasan terhadap petugas PPS dan KPPS.

\section{Daftar pustaka}

Djojodirdjo, M., 1982. Perbuatan Melawan Hukum. Jakarta. Pradnya Paramita.

Isjwara, F., 1999. Pengantar Ilmu Politik. Bandung. Putra A Bandin.

Keban, Yeremias. 2004. Enam Dimensi Strategis Administrasi Publik: Konsep, Teori, dan Isu. Yogyakarta. Gaya Media.

Kitab Undang-Undang Hukum Perdata.

Kitab Undang-Undang Hukum Pidana.
Marzuki, Peter Mahmud. 2005. Penelitian Hukum. Jakarta. Kencana.

Nahudin, Y. (2017). Pemilihan umum dalam sistem demokrasi prespektif sila ke- 4 Pancasila. Jurnal Cakrawala Hukum, 8(2), 240-249. doi:10.26905/ idjch.v8i2.1670.

Peraturan Pemerintah Republik Indonesia Nomor 44 tahun 2015 tentang Badan Penyelenggara Jaminan Sosial.

Rahardjo, Satjitpto. 2000. Ilmu Hukum. Bandung. Citra Aditya Bakti.

Ridwan, HR. 2013. Hukum Administrasi Negara. Jakarta. Rajawali Grafindo Persada.

Safutra I., 2019.326 Orang Petugas Pemilu Meninggal Dunia. www.jawapos.com. Diakses pada tanggal 21 September 2019.

Sofyan, A., Nur Azisa. 2016. Hukum Pidana. Makassar. Pustaka Pena.

Sugiharto, Ignatius B., 1996. Postmodernisme : Tantangan bagi Filsafat. Jakarta. Kanisius.

Tanya, Bernard L., dkk. 2013. Teori Hukum : Strategi tertib Manusia. Yogyakarta. Genta Publisihing.

Undang-Undang Republik Indonesia Nomor 13 tahun 2003 tentang Ketenagakerjaan.

Undang-Undang Republik Indonesia Nomor 5 tahun 2014 tentang Aparatur Sipil Negara.

Widaningsih, W. (2017). Implikasi yuridis atas putusan Mahkamah Koinstitusi tentang penyelenggaraan pemilihan umum serentak tahun 2019. Jurnal Cakrawala Hukum, 19(1), 93-105. doi:10.26905/ idjch.v19i1.1134. 